intensive over-grazing now coincides with a decrease in rainfall, and in the whole of East Africa the most urgent problem is the preservation of many acres of forest. In southern Africa about 30 per cent of the indigenous vegetation has completely disappeared, but interest in plant conservation is growing, and many nature reserves have been established. In west Africa a few carefully placed reserves could embrace a large proportion of the rare endemic species and representative samples of vegetation types and habitats. A large central Kalahari reserve was urged for Botswana in south tropical Africa.

In Madagascar the existing reserves have been placed so as to conserve as many as possible of the types of vegetation found on the island, but there are interesting plants, such as the endemic family Didieriaceae, which still need protection. There are also endemic species on the Seychelles, and these are likely to become extinct unless they are protected soon.

Conservation of vegetation in Africa will not be easy; it can conflict with other projects. In some areas, for example, control measures against tsetse fly and sleeping sickness have involved extensive clearance of interesting forest vegetation. The conference, however, was hopeful and, recognizing the urgency of the situation, decided to select one area from each country where immediate action is most necessary.

\section{Boom in Biology}

The Biological Education Committee appears to be confident that increasing numbers of pupils at British schools will follow courses in biology in the years ahead. On the basis of a survey undertaken in 1965 , the committee considers that there will have been an overall increase of 48 per cent in the numbers sitting Advanced level examinations in biology between 1963 and 1966. The number of Advanced level candidates in 1963 was 12,900 and is expected to have reached 19,100 in 1966. Although a part of this increase is due to the increase of the school population, the committee which supervised the survey considers that there is also a real growth of interest in biological subjects (Biological Sciences in Sixth-forms and at Universities in the United Kingdom, Institute of Biology).

The survey has shown that roughly 29 per cent of the boys now studying biology at British schools do so because they wish to enter medical schools. Intending doctors make up 15 per cent of the girls following biology courses. Although 27 per cent of the girls were intending to become teachers, only 5 per cent of the boys following biology courses were so motivated. In a somewhat clouded sentence which seems to belie its optimism, the committee says that the viability of school biology may depend "on the number of pupils intending to enter medical and similar careers".

The report of the committee includes an attempt at a survey of the present practice of universities, both in the education of undergraduates and in the acceptance of candidates from the schools. It records the emergence of departments and schools at British universities with titles such as Biological Sciences and Molecular Science, the tendency of botanists to be more ready to change their existing courses than the zoologists, and the reluctance of a great many professors of botany and of zoology to see these two subjects amalgamated. The general conclusion is that the teaching of biology will be influenced, in the years immediately ahead, by the movements of curriculum reform now under way, and by the likelihood that biology will play a more important part in general education. The committee considers that the training of biology teachers, both before and during their careers, is the major problem, and suggests that there may be a conflict of interest in the universities between the needs of "future research workers" and of teachers. It is not clear from this just what changes the committee would like to see, and this is one of the ways in which the impact of the survey will be less sharp than it might have been. Another is that the great volume of statistical information in the report has been presented so starkly that it reads more like a railway timetable than a document of public interest.

\section{Cells for Safe Vaccines}

THE economic production of viral vaccines depends on cultures of animal cells which provide a substrate on which viruses can be grown in sufficient numbers. The Committee on Cell Cultures of the International Association of Microbiological Societies collects and distributes information on in vitro tissue culture sub. strates in general, but particularly about those used for virus growth in vaccine production. Its latest report stresses the need to use a substrate free from all detectable contaminants.

For the past twelve years vaccine makers have used primary non-human cell cultures-cell populations derived from animal tissue in its first in vitro culture and which has not been sub-cultivated. These have been found to have undesirable properties, however, chiefly because of contamination by unwanted viruses. Cultures of cells from the rhesus monkey, for example, can be inherently infected with simian virus 40 , and this was found as a contaminant in some inactivated poliomyelitis vaccines prepared six years ago from cultures of these cells; simian virus 40 is known to cause the production of tumours in hamsters. Another danger inherent in cultures which are contaminated with unwanted viruses results from viral hybridization. Material from simian virus 40 can unite with adenovirus 4-responsible for some human respiratory disorders-when the two are grown together on the same substrate. The hybrid is a virus which is serologically adenovirus, but which can also cause the development of tumours in the cheek pouch of the hamster. The presence of such a hybrid in an adenovirus vaccine is obviously dangerous.

Pure cultures are the objective, but purity is not assured by the current practice in which new cell populations are continuously derived from fresh animal tissue. Contamination can be more easily avoided when serially cultured cell strains are used as substrate. A single tissue from a single donor can be sub-cultured to give large quantities of a diploid cell strain, which can be stored at low temperatures and thoroughly examined for contamination before use. This makes possible the provision of a uniform and fully characterized standard stock of seed cells which can be used as the basis of cultures for the production of large quantities of a number of viral vaccines. The use of human cells for this purpose is obligatory for at least one group of viruses-the rhinoviruses-which are the cause of unpleasant respiratory disorders in children, and which grow poorly or not at all in other than human diploid cells. 